り難いと考えられる。乙れは実用的には有利である。 形状計測を高速に行う場合，数回測定して平均をとる 余裕はない，対象が幾何学的図形のとき，最大と最小の
差を小さくするという意味では平均値 0 のノイズを重量 するとと屯考えられる。つまり分散は一定でも分布の形 がガウス曲線に近くなる。

\title{
高圧 $\mathrm{Ar}-\mathrm{CO}_{2}$ 混合ガス雾囲気下でアーク溶接した 鋼溶接金属の機械的性質*
}

\author{
桑名 武**，粉川 博之**，木口 立而**
}

Mechanical Properties of Mild Steel Weld Metals Produced in

Pressurized $\mathrm{Ar}-\mathrm{CO}_{2}$ Atmospheres*

by Takeshi Kuwana**, Hiroyuki Kokawa** and Ryuji Kiguchi**

Mild steel sheets with $\mathrm{V}$-groove were welded in pressurized $\mathrm{Ar}-\mathrm{CO}_{2}$ gas mixture atmospheres up to $2.0 \mathrm{MPa}$, using a $1.6 \mathrm{~mm}$ diameter solid wire. The effect of ambient gas pressure and gas composition on the mechanical properties of weld metals were studied. The Vickers hardness and tensile properties of weld metals were varied with the ambient gas composition but did not depend on the ambient gas pressure. The Charpy $\mathrm{V}$ notch toughness of weld metal was changed markedly with $\mathrm{CO}_{2}$ partial pressure in the atmosphere, and showed a maximum at $0.1 \sim 0.2 \mathrm{MPa} \mathrm{CO}_{2}$ partial pressure which resulted in about $0.03 \%$ oxygen content of weld metal having a fine ferrite microstructure. This suggests that toughness is strongly influenced by the oxygen content of weld metal. Mechanical properties of pressurized steel weld metal can be controlled by $\mathrm{CO}_{2} \%$ in the welding atmosphere, because the oxygen content of weld metal is determined by $\mathrm{CO}_{2}$ partial pressure.

Key Words: Hyperbaric welding, Mild steel weld metal, Pressurized Ar-C.O $\mathrm{O}_{2}$ atmosphere, Effect of ambient pressure, Toughness of weld metal, Tensile properties of weld metal, Chemical compositions of weld metal, Oxygen content of weld metal.

\section{1. 緒言}

海洋開発などの必要性から各種溶接法による水中溶接 に関する研究が多くなされており ${ }^{-9}$ ，著者らはてれま で乾式水中溶接に関する基礎的資料を得る目的で高圧罢 囲気下での鋁のアーク溶接について研究を行ってきた。 前報8,9) では，活性ガスとしての $\mathrm{CO}_{2}$ に注目して0.1〜 2. $0 \mathrm{MPa}$ の高圧 $\mathrm{Ar}-\mathrm{CO}_{2}$ 混合ガス雾囲気下で鋼のアーク 溶接を行い, 電極線の溶融率, ビード形状, 溶接過程にお ける合金元素の挙動などに及ぼす雾围気圧力及び $\mathrm{CO}_{2}$ 分圧の影響を調へた。 その結果, 雰团気圧 $2.0 \mathrm{MPa}$ ま で諸溶接欠陥が極めて少なく比較的良好な溶接を行うこ とが可能であることを示した。また，溶接金属中の酸素 量が雾囲気压力及び $\mathrm{CO}_{2}$ 分圧に大きく依存して変化し, それに応じて $\mathrm{Si}, \mathrm{Mn}, \mathrm{Ti}$ 等の脱酸元素含有量が変化す るととが分かった。このような合元元素の挙動は溶接金 属の諸性實とくに機械的性質に大きな影響を与えるとと が予想される. そこで本研究では，需团気圧 $0.1 \sim 2.0$ $\mathrm{MPa} の \mathrm{Ar}-\mathrm{CO}_{2}$ 混合ガス䨌囲気下で鋼のアーク溶接を 行ない，溶接金属の靬性，引張特性，硬さなどに及活す 票围気圧力及び $\mathrm{CO}_{2}$ 分圧の影䱥について検討を行った。

\section{2. 実 臨方 法}

使用した軟銅電極線（直径 $1.6 \mathrm{~mm}$ ) 及び母材 $(\mathrm{SS} 41$

\footnotetext{
*原稿受付 平成 2 年 7 月 23 日 平成元年度秋季全国大会で発表

**正 員 東北大学工学部 Member, Faculty of Engineering, Tohoku Univ.
}

厚さ $12 \mathrm{~mm}$ ) は前報8,92 とほぼ同じであるが, それらの 化学組成を Table 1 亿示す. Table 2 に示したような形 状の開先付母材鋼板 $(200 \times 250 \times 12 \mathrm{~mm})$ を溶接雲囲気

Table 1 Chemical compositions of electrode wire and base plate (mass $\%$ )

\begin{tabular}{|c|c|c|c|c|c|}
\hline & $\mathrm{C}$ & $\mathrm{Si}$ & $\mathrm{Mn}$ & $\mathrm{Ti}$ & 0 \\
\hline $\begin{array}{c}\text { Electrode } \\
\text { wire }\end{array}$ & 0.07 & 0.75 & 1.48 & 0.14 & 0.0023 \\
\hline $\begin{array}{c}\text { Base } \\
\text { plate }\end{array}$ & 0.18 & 0.20 & 0.46 & - & 0.0094 \\
\hline
\end{tabular}

Table 2 Welding conditions used

\begin{tabular}{|c|c|c|c|}
\hline $\begin{array}{l}\text { Arc } \\
\text { Voltoge }\end{array}$ & $\begin{array}{l}\text { Welding } \\
\text { Current }\end{array}$ & $\begin{array}{l}\text { Heat } \\
\text { Input }\end{array}$ & $\begin{array}{l}\text { Atmosphere and } \\
\text { Pressure }\end{array}$ \\
\hline$\sum_{40}^{33} v$ & $\begin{array}{c}330 \\
380\end{array} A$ & $\begin{array}{l}3.5 \\
\mathrm{~kJ} / \mathrm{mm}\end{array}$ & $\begin{array}{l}\mathrm{Ar} . \mathrm{Ar}-10.20 .50 \% \mathrm{CO}_{2} \\
\mathrm{CO}_{2} . \\
0.1 \sim 2.0 \mathrm{MPa} \text { abs }\end{array}$ \\
\hline
\end{tabular}

Di: ect Current Electrode Positive

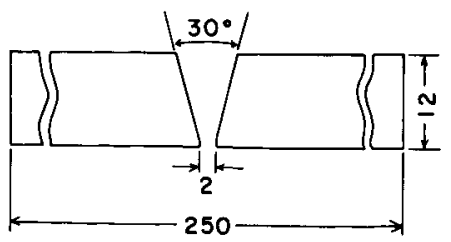


調整装罾（容積約 $1 \mathrm{~m}^{3}$ ) 内にセットし, 装置内を $66 \mathrm{~Pa}$ 以下に排気した後, $\mathrm{CO}_{2}$ 及び $\mathrm{Ar}$ ガスをそれぞれ所定の 生力（最高全压 $2.0 \mathrm{MPa}$ ) まで封入することによって高 圧 $\mathrm{Ar}-\mathrm{CO}_{2}$ 漉合力゙ス赫国気を作り，10分間擋拌後，消 耗電極法（電極線正）により塑層盛り溶接で突合せ継手 を完成させた，Table 2 に溶接条件を示す，完全浴り込 みでアンダカットのない継手を得るため，アーク電圧, 溶接電流は多少変化させているが，溶接速度 $3.3 \mathrm{~mm} /$ sec 一定亡し入熱量は常に約 $3.5 \mathrm{~kJ} / \mathrm{mm}$ 亡なるように した。繁㘫気組成は， $\mathrm{Ar}-\mathrm{CO}_{2}$ 混合ガス中の $\mathrm{CO}_{2}$ ガス \%を $0 \sim 100 \%$ と変化させ, 全王を $0.1 \sim 2.0 \mathrm{MPa}$ の範 囲で変えた。

溶接後, 溶接部の外䚒, $\mathrm{X}$ 線透過試験, 光学顕微鏡組 織観察，ビッカ一ス硬さ测定を行ったのち，溶接継手か ら弓張試験片またはシャルピー衝撃試験片を Fig.1 の ように切り出した。すなわち，引張試驗には溶接金属部

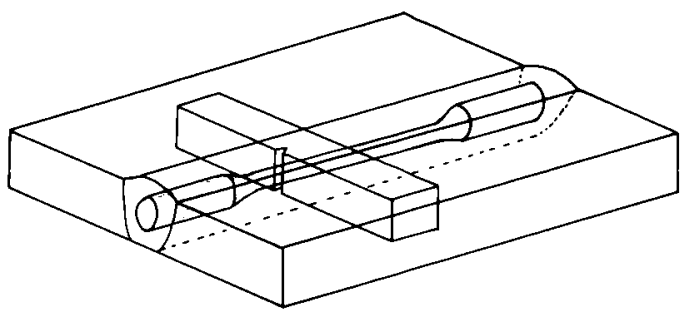

Fig. 1 Sketch of welded specimen showing location of test specimens for mechanical tests.

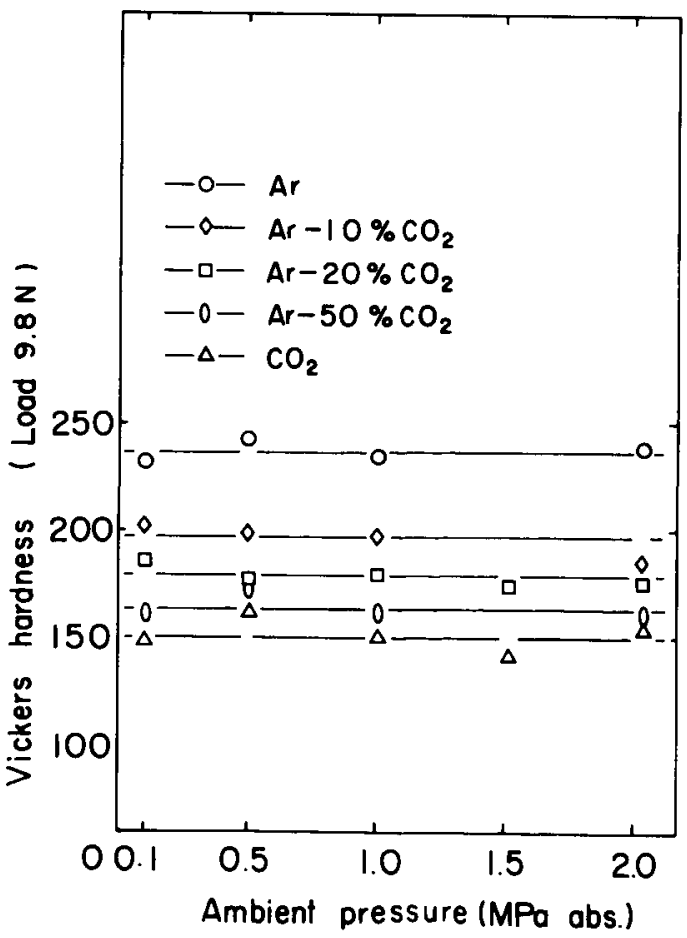

Fig. 2 Relationship between the Vickers hardness of weld metal and the ambinet gas pressure.
より溶接線方向に JISZ 3111 の A 2 号試験片（平行部

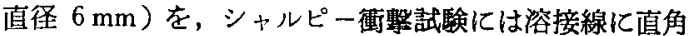
で溶接金属中央部に板厚方向の $2 \mathrm{~mm} \mathrm{V/ッチをつけ}$ た JISZ 2202 の 4 号試験片を作製した。 引張試験は室温 でクロスヘッドスピード $0.5 \mathrm{~mm} / \mathrm{min}$ で行い，衝輇試 験は, 試験温度 $273 \mathrm{~K}$ に $1.8 \mathrm{ks}(30 \mathrm{~min})$ 以上保持した のちシャルピー衝撃試験機を用いて行った。

また，溶接金属部加ら分析試料屯採取し，各元素の定 量を, 炭素は電量测定法, ケイ素は重量法, マンガンと チタン（全チタン）は原子吸光光度法, 酸素はアルゴン 気流中溶辟電量測定法で行った。

\section{3. 実 験 結 果}

\section{1 溶接金属のビッカース硬さ}

Fig. 2 は, 溶接金属中央部のビッカース硬さをビード 表面側から裹面に向かって $1 \mathrm{~mm}$ 間隔で測定し，その平 均值と需囲気圧の関係を示したものである。いずれの学 因気組成においても寄团気圧の増加による溶接金属の硬 さの変化はほとんどない，また，同一雲囲気圧では雷囲 気中の $\mathrm{CO}_{2} \%$ \%増加ととあに硬さは娍少している。

\section{2 溶接金属の引張特性}

Fig. 3 は，溶接金属の室温におりる引張特性（引張強 さ $\sigma_{\mathrm{B}}$, 降伏応力 $\left(0.2 \%\right.$ 耐力) $\sigma_{0.2}$, 伸び $\varepsilon$, 紋り $\left.\phi\right)$ と䨌囲気圷の関係を示したものである、いずれの雾囲気 組成においても，乙れら引張特性に対する雰团気圧の影

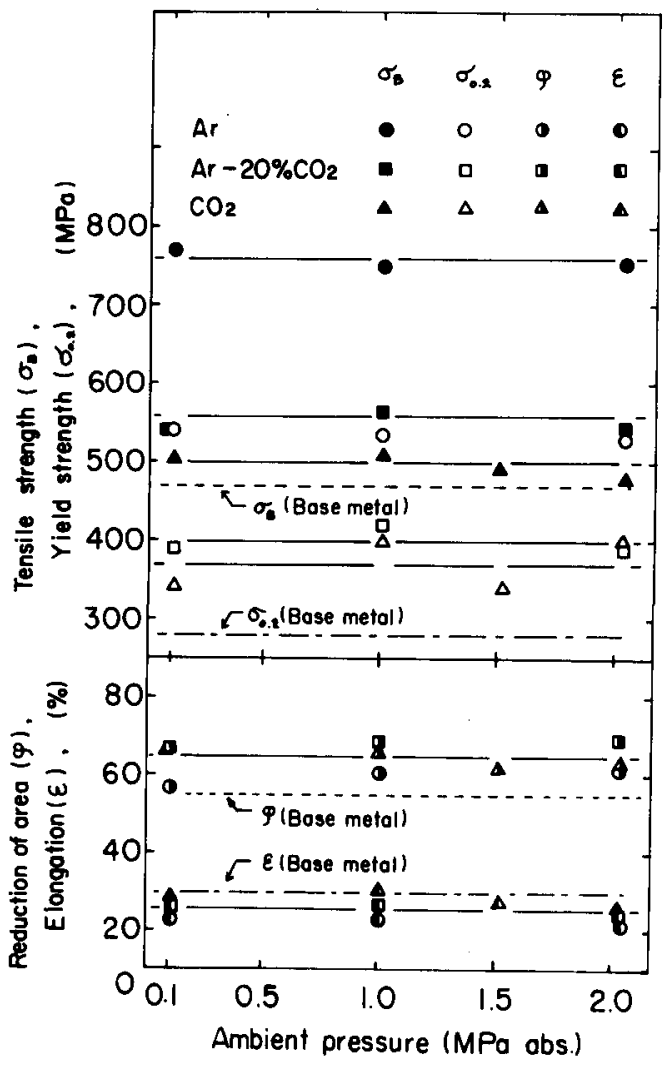

Fig. 3 Relationship between the tensile properties of weld metal at room temperature and the ambient gas pressure. 


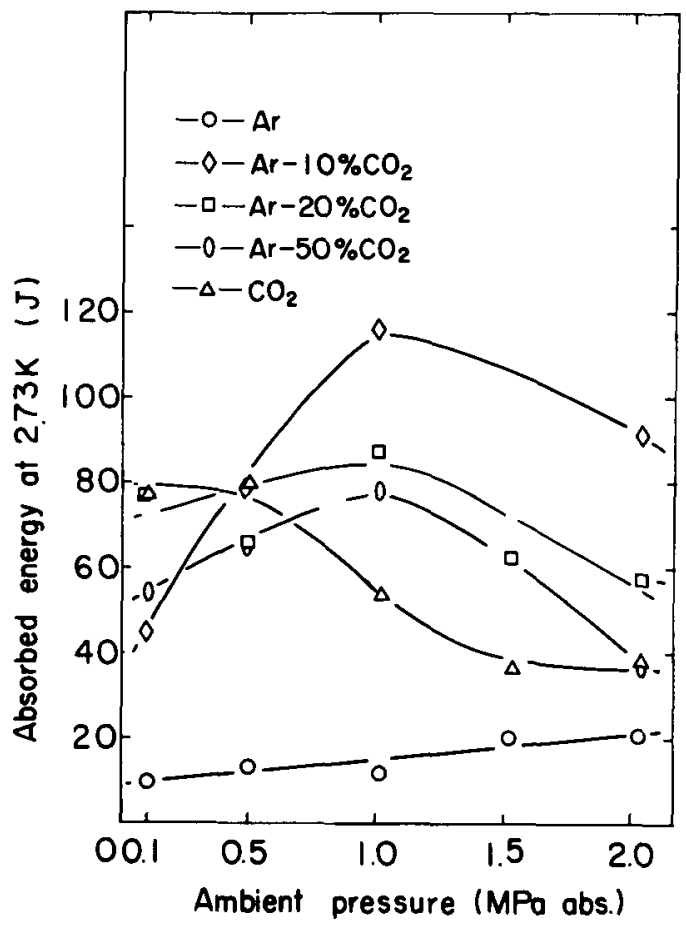

Fig. 4 Relationship between the Charpy impact property of weld metal at $273 \mathrm{~K}$ and the ambient gas pressure.

踾はほとんど見られず，いずれすほほ一定の值を示して

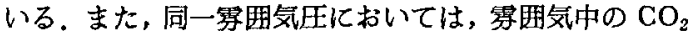
\%が増すにつれて引張強さと降伏応力は娍少する㑯向が 認められるが，伸びと较りにはほとんど差がない，同図 中に点線で母材の引張特性值を示してあるが，いずれの 溶接金属の引張特性も母材之同程度あるいはそれ以上の 值を示している.

\section{3 溶接金局の䩒性}

Fig. 4 は，溶接金属のシャルピ一衙撃吸収エネルギー 之雾囲気圧の関係を試験温度 $273 \mathrm{~K}$ の場合について示 したものである。なお，図中の值は 3 試験片以上の测 定平均值を示している。Ar 票团気の場合, 吸収エネル ギーは雾国気圧の増加とと6に僅かに増す傾向がある が, 2.0 MPa においても $20 \mathrm{~J}$ と全体的に極めて低い值 である. $\mathrm{CO}_{2}$ 雾囲気の場合, 吸収エネルギーは雾囲気 压が $0.5 \mathrm{MPa}$ 以上になると票囲気圧の増加ととあに減 少し, $1.5 \mathrm{MPa}$ 以上では䄪 $40 \mathrm{~J}$ と大気圧 $(0.1 \mathrm{MPa}) の$ 場合の半分程度となっている。 また, $\mathrm{Ar}-\mathrm{CO}_{2}$ 混合ガス 雺囲気の場合，同一 $\mathrm{CO}_{2} \%$ 雾囲気であ穿围気圧が変 わると靶性が大きく変化し，ある罢团気压で極大值を示 す。すなわち，军囲気圧によって最良の知性を示す溶接 金属が得られる $\mathrm{CO}_{2} \%$ が異なる。

\section{4 溶接金局の化学組成}

Fig. 5 は, 溶接金属の C, Si, Mn, Ti 含有量と雺囲 気圧の関係を示したあのである，C はいずれの雾囲気組 成, 雾囲気压において60.12〜0.13\%では亡んど変化は ない，また，Si，Mn，Ti 合有量は雲囲気圧が一定の場 合, 雾囲気の $\mathrm{CO}_{2} \%$ が多いほど少なくなっている。し

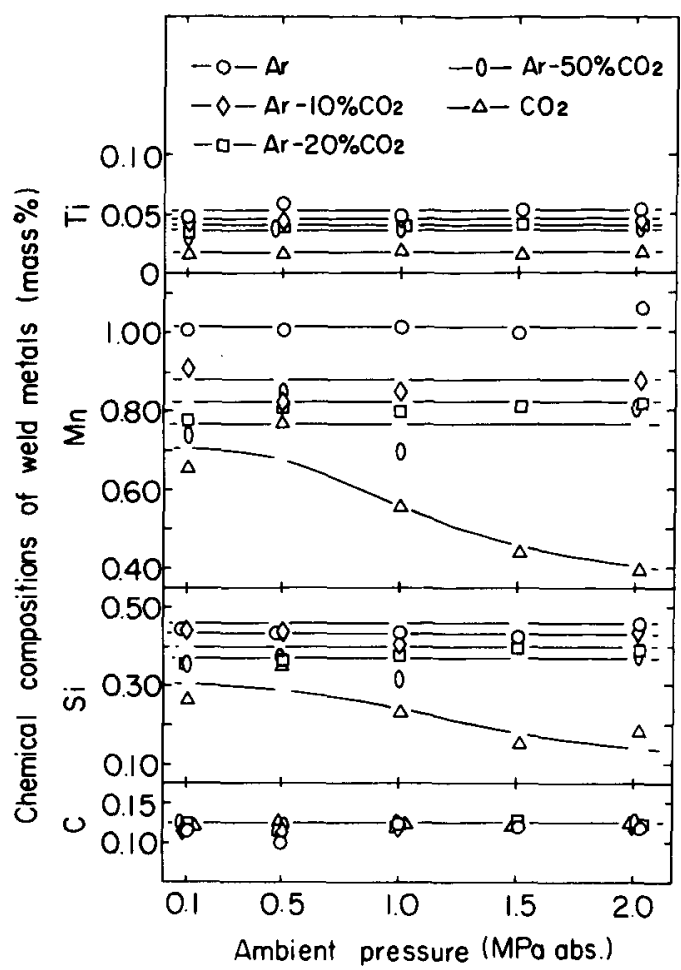

Fig. 5 Relationship between the chemical compositions of weld metal and the ambient gas pressure.

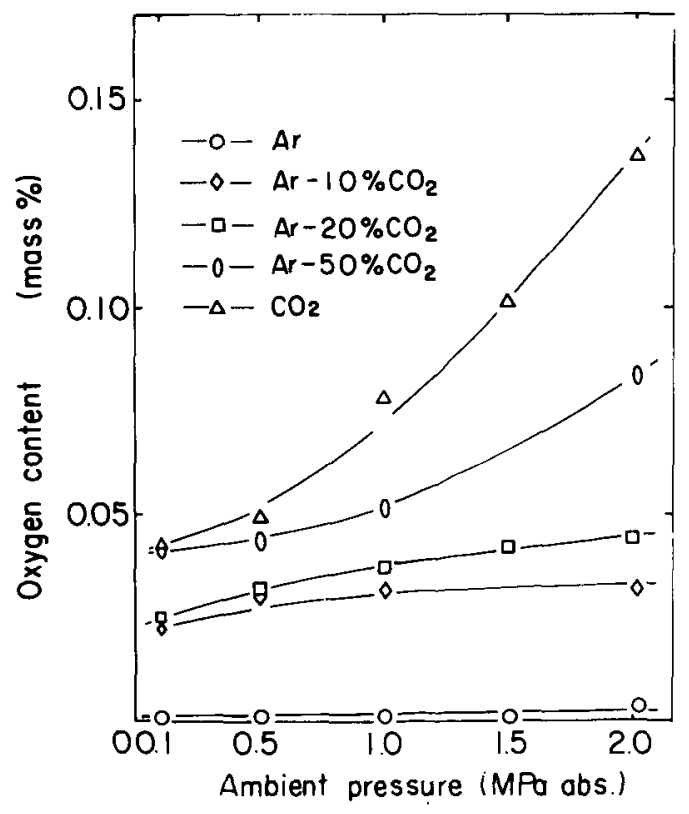

Fig. 6 Relationship between the oxygen content of weld metal and the ambient gas pressure.

加し，雲四気組成が一定の場合，乙れらの元素は $\mathrm{CO}_{2}$ 雾围気以外，需囲気压の影罄を受けずほぼ一定となって 
いる.

Fig. 6 は, 溶接金属の酸素含有量と䨌囲気圧の関係を 示したものである. 雾囲気中に $\mathrm{CO}_{2}$ が含まれる場合, 需囲気圧の増加之之屯に酸素含有量は増加している。 の傾向は $\mathrm{CO}_{2} \%$ が高くなる程顕著である.

3.5 溶接金属のミクロ組織

Fig. 7 は, 溶接金属中央部の光学顕微鏡組織例を示し たあのである. Ar 雾囲気 $0.1 \mathrm{MPa}$ の場合 (Fig. 7 a) 粒

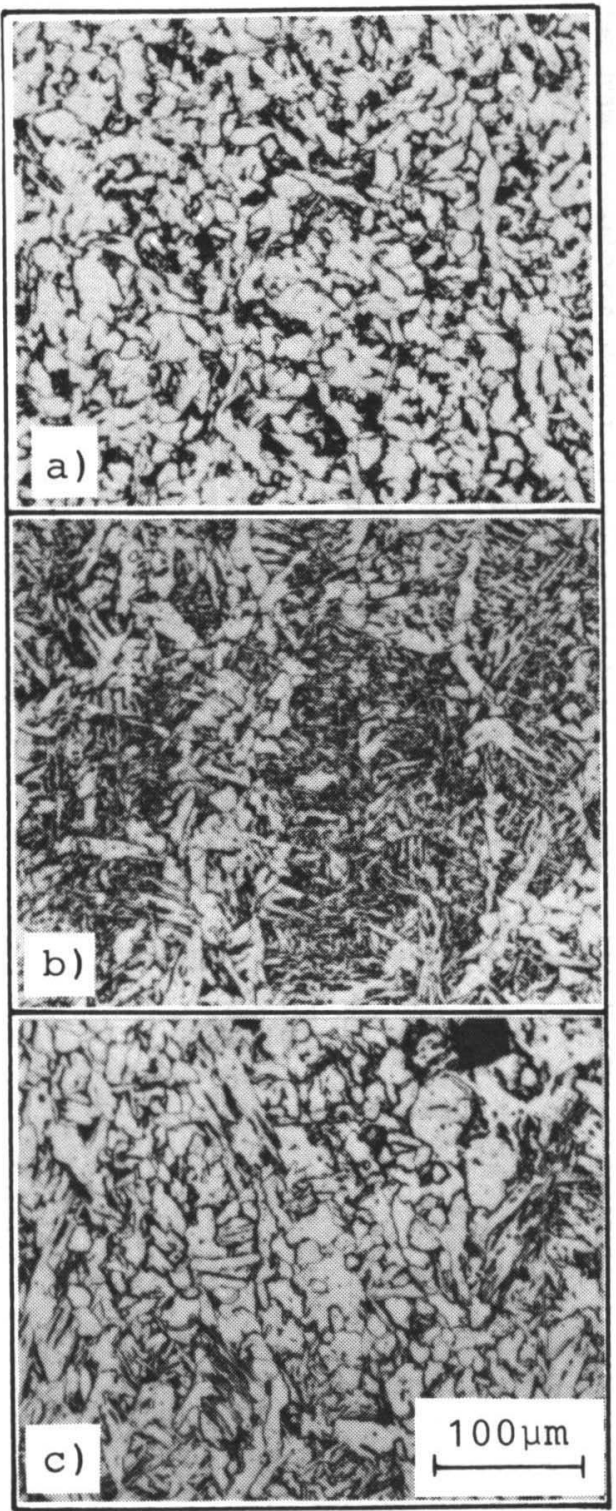

Fig. 7 Microstructure of weld metal.

a) $\mathrm{Ar}$ atmosphere $\left(\mathrm{P}_{\text {total }}=0.1 \mathrm{MPa}, 0.001\right.$ $\%$ O $)$

b) $\mathrm{Ar}-20 \% \mathrm{CO}_{2}$ atmosphere $\left(\mathrm{P}_{\text {total }}=1.0\right.$ $\mathrm{MPa}, 0.036 \%$ O)

c) $\mathrm{CO}_{2}$ atmosphere $\left(\mathbf{P}_{\text {total }}=2.0 \mathrm{MPa}\right.$, $0.136 \% \underline{\text { O) }}$
状フェライトが大部分を占めており, $\mathrm{Ar}-20 \% \mathrm{CO}_{2}$ 雾囲 気 $1.0 \mathrm{MPa}$ の場合 (Fig. $7 \mathrm{~b}$ ) 粒界フェライトおよび フェライトサイト゚プレートが発達し粒内には微細フェラ イトが多く見られ，乙れらがほぼ均等に分布している. $\mathrm{CO}_{2}$ 霝囲気 $2.0 \mathrm{MPa}$ の場合 (Fig. $7 \mathrm{c}$ ), 粒界フェライ ト, フェライトサイドプレート, 微紐フェライトからな っているが, 微紐フェライトの占める割合が少なくなっ ている.

$\mathrm{Ar}-\mathrm{CO}_{2}$ 雲囲気溶接金属組織中には Fig. 8 に見られる ような球形の酸化物系介在物がしばしば観察された。 そ こで, 溶接金属中の酸化物系介在物の体積分率と酸素含 有量の関係を調へ Fig. 9 に示した. この図から, 酸化物 介在物量は雲囲気組成の違いによらず溶接金属の酸素含 有量の増加とともに増加していることがわかる。

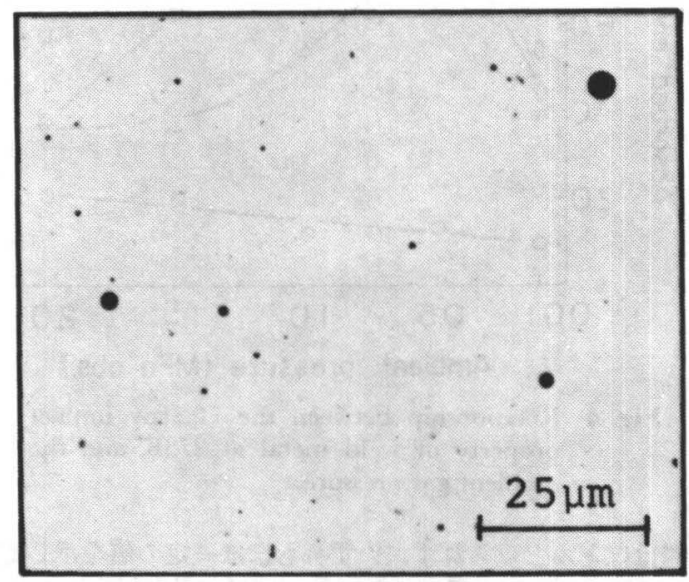

Fig. 8 Nonmetallic inclusions in the weld metal made in $\mathrm{Ar}-20 \% \mathrm{CO}_{2}$ atmosphere $\left(\mathrm{P}_{\text {total }}=\right.$ $2.0 \mathrm{MPa}, 0.044 \% \underline{\mathrm{O}})$.

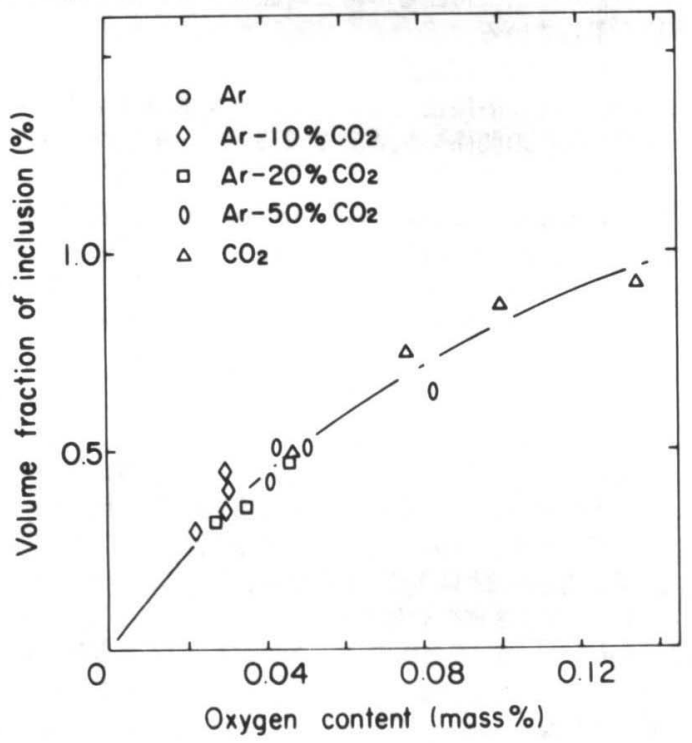

Fig. 9 Relationship between the volume fraction of inclusion and the oxygen content. 


\section{4. 考}

\section{察}

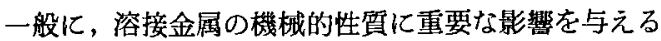
因子としては，その化学組成とミクロ組織が挙げられ る。このような観点加ら本実験結果について以下のよう な考察を行った。

本実験において, 高压 $\mathrm{Ar}-\mathrm{CO}_{2}$ 混合ガス雾囲気下で 得られた鏩溶接金属の機珹的性䫓を調べた結果，ビッ カース硬さ及び引張特性は霖囲気圧の影響をほとんど受 けずほは一定の值を示した。また，同一雲囲気圧では雲 团気中の $\mathrm{CO}_{2} \%$ の增加とと屯に硬さ，降伏応力，引張 強さは減少した。これらは溶接金属中の化学組成で定性 的飞説明するととが出来る，すなわち， $\mathrm{Si}, \mathrm{Mn}, \mathrm{Ti}$ 等 の合金元素による固溶硬化等が溶接金属の硬さ，引張特 性に影掣を及ばすと考えられる。Fig. 5 亿見られるよう

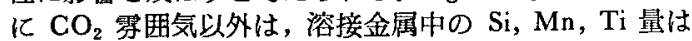
霛囲気の $\mathrm{CO}_{2} \%$ が増すと減少するが雾囲気圧に上る変 化はほとんどなく，Fig. 2 と 3 の硬さ，引張特性はその 組成変化にほほ対灾している。

$\mathrm{CO}_{2}$ 需团気の場合の硬さ，引張特性と $\mathrm{Si}, \mathrm{Mn}$ 量の 変化は対応していないが，これは Fig. 6 のように $\mathrm{CO}_{2}$ 雱囲気の場合には溶接金属中の酸素含有量が雾囲気压の 増加とともに急激偪加しているととと関連しているか あしれない。

なお，溶接金属の化学組成に及ぼす雾囲気ガス組成， 圧力の影響はビード・オン・プレートの場合と同様, 溶 接雾围気の酸化ポテンシャルと関連すると思われ，既 報》で考察している.

一方，溶接金属の靬性変化は，Fig.4 に見られるよう に単純ではない。同一 $\mathrm{CO}_{2} \%$ の雲囲気であ雾囲気圧が 変わると靬性汃大きく変化し，また，それぞれの霝团気 組成仙応して異なった極大值を示すことから, Fig. 4 の 衝撃吸収エネルギーを需囲気中の $\mathrm{CO}_{2}$ 分圧 $\left(\mathrm{P}_{\mathrm{CO}_{2}}\right)$ で 整理したのが Fig. 10 である.いずれの雾囲気組成にお いてあ，溶接金属の勒性は $\mathrm{CO}_{2}$ 分压加增すととあに急 激に增加し，ある程度以上 $\mathrm{P}_{\mathrm{CO}_{2}}$ が増す之再び䩗性が 低下している。雾聿気組成によって勒性の極大值に違い はあるあのの, $\mathrm{PCO}_{2}$ が $0.1 \sim 0.2 \mathrm{MPa}$ 付近に靬性の極大 が存在している。とてろで，伊藤ら ${ }^{10-13)} は$ ，䤡のサブ マージおよびガス・メタルアーク溶接金属の靱性が $\mathrm{Si}$, $\mathrm{Ti}, \mathrm{O}$ 含有量に依存し，乙れらの元素が溶接金属中に 適正量含まれる場合に鞓性は極大值を示すととを報告 している。本溶接金属の場合，Fig. 5 から分かるよう に Ar-CO ${ }_{2}$ 混合ガス雾团気では雾围気压の增加による $\mathrm{Si}, \mathrm{Mn}, \mathrm{Ti}$ 含有量変化はあまり大きくない，一方，溶接 金属の酸素量は，Fig. 6 亿示すように雾囲気圧及び組成 に依存して大きく変化している。また，ての酸素量は既 報9)で述べたごとく $\mathrm{P}_{\mathrm{CO}_{2}}$ で一義的には整理できない。

そのために Fig. 10 のように靬性が極大を示す $\mathrm{P}_{\mathrm{CO}_{2}}$ が 幅を持つと思われる。そこてで，Fig.11 亿溶接金属の酸素 量と䔆撃吸収エネルギーの関係を整理してみた，との図 から浴接金属の酸素量が0.03\%付近のところに勒性の極 大があることが分かる。酸菜量を $0.03 \%$ 程度含む溶接金 属租織は Fig. $7 \mathrm{~b}$ のように微細フェライトが多く認めら れ，それより酸素量が多くても（Fig. 7c）少なくても (Fig. 7a) 組織が粗くなる傾向にあり，乙のような酸素 量変化にとあなうミク口組織の変化が鞂性の極大をむた らしたあのと考えられる。酸素は固体鉄中にほとんど固

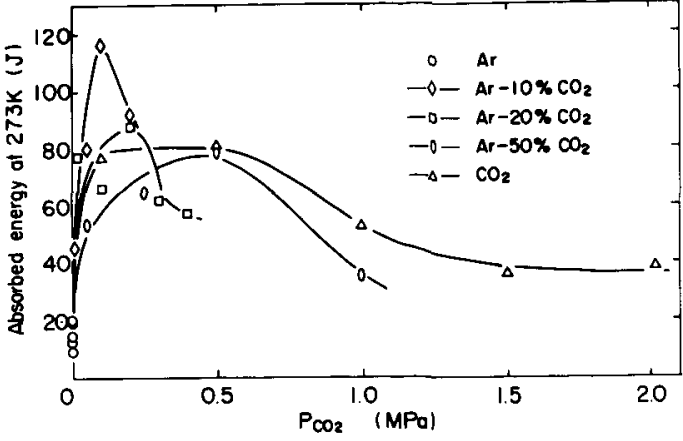

Fig. 10 E.ffect of $\mathrm{CO}_{2}$ partial pressure on the Charpy impact property of weld metal at $273 \mathrm{~K}$.

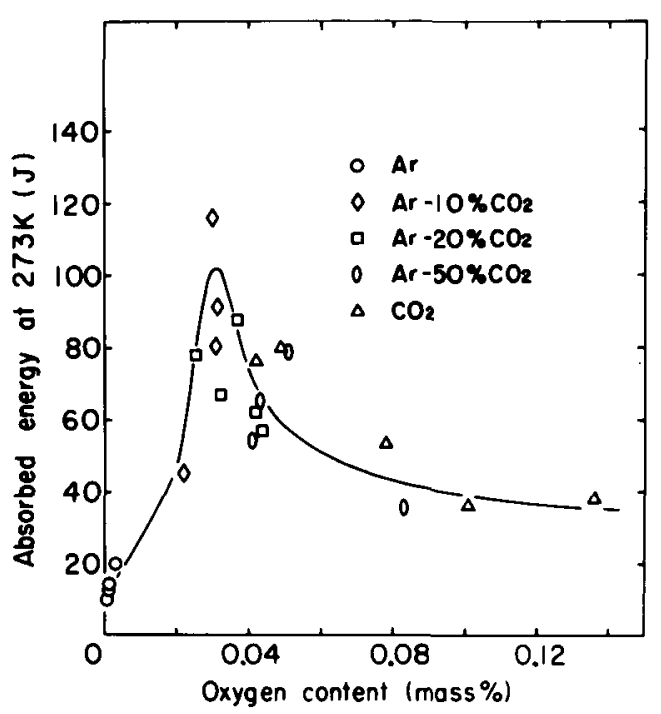

Fig. 11 Fffect of oxygen content on the Charpy impact property of weld metal.

溶しないため，その大部分は酸化物として鋼溶接金属に 存在する ${ }^{14)}$. 実際 Fig. 9 に見られるように，溶接金属中 の酸化物量は, 雲囲気組成, 圧力によらず酸素量にのみ 依存している，そして適当量の酸素量によってできた酸 化物系介在物が微細（アシキュラー）フェライト組織を 生じ13), 靱性を向上させるあのと思われる。従って，本 实験の場合, 良好な靶性が得られる溶接金属の酸素量は $0.03 \%$ 程度と考えられる. 著者らの圧力 $0.1 \mathrm{MPa}$ の Ar$\mathrm{CO}_{2}$ 混合ガス察囲気下でアーク溶接した場合の研究結 果15-17) から, 溶接条件が-一定で化学組成が同じなら鋼 溶接金属の酸素量は需囲気の $\mathrm{CO}_{2}$ 分圧のみに依存する 之考元られる。本実験の高玨雲囲気下においても雲囲気 压，組成にあまり体存せず， $\mathrm{CO}_{2}$ 分圧が $0.1 \sim 0.2 \mathrm{MPa}$ の場合に0.03\%程度の酸素量が得られている。以上のと とから，適正な $\mathrm{CO}_{2}$ 分圧が得られるように雺囲気の $\mathrm{CO}_{2} \%$ を選ふてとに依って，適正な酸素量で微綀つェ ライト組織を有する銅溶接金属を得ることが出来る.

最後に，本実験で得られた溶接金属の機械的性䨘を溶 接構造用圧延鋼材 SM 41 B (JISG 3106) ${ }^{18}$ ) のそれと比 
較してみると, 純 $\mathrm{Ar}$ 雾囲気以外の雱囲気で溶接された 溶接金属の靱性はすべての雲囲気圧において規格を満足 している.また，引張特性についてはいずれの算囲気で あ問題ない，機械的性質に関してはこのように溶接条件 （雾用気ガス租成）の調節で一応満足すべきものが得ら れる。しかし，溶接構造物として見る場合，外锤む重要 である，その点からすれば, $\mathrm{Ar}-\mathrm{CO}_{2}$ 混合ガス㖒囲気を 用いた方が， $\mathrm{CO}_{2}$ 塞围気のように等用気圧が $1.0 \mathrm{MPa}$ 以上でのビード蛇行, アンダーカット，オーバラップの 発生むなく，良好な外観の溶接金属が得ら扎ることから 適当之考えられる。

\section{5. 結 論}

$0.1 \sim 2.0 \mathrm{MPa}$ の高压 $\mathrm{Ar}-\mathrm{CO}_{2}$ 混合ガス雾囲気中で， 軟鋼の開先継手溶接を行い，溶接金属の機珹的性筫を調 べ次のような結果が得られた。

1. 溶接金属のビッカース硬さは，いずれの雰团気組 成においても票囲気压の増加による変化はほとんどなか ったが，同一雾囲気圧では雾囲気中の $\mathrm{CO}_{2} \%$ の增加と とあに減少した。

2. 溶接金属の弓張特性は，いずれの雾囲気組成にお いてす雾囲気圧の影響はほとんど見られず，いずれむほ 将一定の值を示した。 また，同一雲用気圧においては， 界囲気中の $\mathrm{CO}_{2} \%$ が増すにつれて引張強さ之降伏強さ は減少する傾向が認められたが，伸びと絞りにはほとん ど帘化がなかった。

3. 溶接金属の䇝性は, 同一 $\mathrm{CO}_{2} \%$ の雪团気圧が変 わると勒性が変化しまた，それぞれの雲囲気組成に応じ て異なった極大值を示した。靱性は雾围気の $\mathrm{CO}_{2}$ 分圧 が $0.1 \sim 0.2 \mathrm{MPa}$ 付近で極大となり，その時溶接金属の 酸素量は $0.03 \%$ 程度であり, 微細フェライト組織を示し た.

4. 溶接金属の機械的特性を，化学組成，ミク口租 織, 酸素量と関係づけて説明することが出来た。 そし て，雺囲気中の $\mathrm{CO}_{2} \%$ を制御することによって良好な 機械的性質を有する鋼溶接金属を得るととが出来るとと が示された。

\section{謝 辞}

終わりに臨み, 本実験に協力された高森 晋, 早川值 截, 栗山真次各工学士および東北大学工学部本田 明技 官に深く感謝する. また，本研究は文部省科学研究費の
授助を受けて行われたてとを付記し，謝意を麦する。

\section{参文 献}

1) Proc. IIW Conference on Underwater Welding, Pergamon Press, London, (1983).

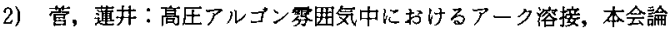
文集, 4-4 (1986), 691-696.

3）屋良，真吉志，菊田，松田：湿式水中アーク溶接に関する研究 (第3報)，本会論文集， 3-2 (1985), 392-397.

4) 西口, 松縄, 堀：高圷アルゴン気中におけるアーク特性, 本誌, $46-8$ (1977), 553-560.

5) M. Perlmann, A. W. Pense and R. D. Stout : Ambient pressure effects on gas - metal-arc welding of mild steel, Weld. J., $48-6$ (1969), 231s-238s.

6) 浿城, 菊地, 堀之内, 上田：高圧Ar军柬気下に括けるMIG溶接 に関する研究, 本会論文集, 7-1 (1989), 56-63.

7) 中山, 山下, 尾崎, 服部：高圧蔡囲気下のアーク溶接について, 本誌, $50-8(1981), 795-800$.

8）桑名, 木口：高压 $\mathrm{CO}_{2}$ 雲囲気における鋼のアーク溶接, 本会論文 集, 2-4 (1984), 625-632.

9)桑名，木口：高圧Arおよび $\mathrm{Ar}-20 \% \mathrm{CO}_{2}$ 靁国気における鋼の アーク溶接, 本会論文集, 6-2 (1988), 256-261.

10）伊藤, 中西：溶接部の䩛性に関する研究 (第1 報), 本誌, 449 (1975), $728-733$.

11）伊藤, 中西：谘接部の鞄性に関する研究（第2 報), 本誌, 4410 (1975), 815-821.

12）伊藤，小西，小粪：溶接金属の連続冷却変態挙動におよほす酸 素の影響, 本誌, 50-12 (1981), 1211-1218.

13) Y. Ito, M. Nakanishi and Y. Komizo : Effects of Oxygen on Low Carbon Steel Weld Metal, Metal Const., 14-9 (1982), $472-478$.

14）桑名, 佐藤：アーク溶接過程における鉄溶接金属の酸索吸収と 酸化物系介在物について，本会論文集，5-3 (1987), 396-402.

15）名，佐藤： $\mathrm{Ar}-\mathrm{CO}_{2}$ 㳫团気における鉄溶接金属の酸素吸収に ついて一アーク溶接過程における鉄溶接金属の酸素吸収につい $\tau$ (第2報) 一, 本会論文集, 1-1 (1983), 16-21.

16) 桑名, 佐藤 : $\mathrm{Fe}-\mathrm{Si}$ 溶接金属の酸素吸収についてーアーク溶接 過程における銅溶接金属の酸素吸収におよほす合金元素の影響 (第1報) 一，本会論文集，7-1 (1989), 43-49.

17) 名,佐藤： $\mathrm{Fe}-\mathrm{Mn} お$ よひ $\mathrm{Fe}-\mathrm{Si}-\mathrm{Mn}$ 溶接金属の酸索吸収に ついてーアーク溶接過程における銅溶接金属の酸素吸収におよ ほす合金元妾の影響 (第2報)一，本会論文集， 7-1 (1989), 4956.

18) JIS：溶接構造用压延鋼材（G3106）. 